\title{
Successful device closure of a ruptured sinus of Valsalva aneurysm presenting with acute heart failure
}

\author{
Kunal Mahajan, ${ }^{1}$ Sanjeev Asotra, ${ }^{2}$ Prakash Negi, ${ }^{2}$ Rajeev Merwaha ${ }^{2}$
}

'Department of Cardiology, IGMC Shimla, Shimla, Himachal Pradesh, India ${ }^{2}$ IGMC Shimla, Shimla, Himachal Pradesh, India

Correspondence to Dr Kunal Mahajan, kunalmahajan442@gmail.com

Accepted 15 October 2015
CrossMark

\section{To cite: Mahajan $\mathrm{K}$} Asotra S, Negi P, et al. BM Case Rep Published online: [please include Day Month Year] doi:10.1136/bcr-2015212883

\section{DESCRIPTION}

A sinus of Valsalva aneurysm (SVA) is an uncommon cardiac anomaly that can be congenital or acquired. SVAs were present in 0.09\% of cadavers in a large autopsy series and ranged between $0.14-0.23 \%$ in a Western surgical series. ${ }^{1} \mathrm{~A}$ congenital SVA is usually clinically silent but may vary from a mild, asymptomatic dilation detected in routine two-dimensional echocardiography, to symptomatic presentations related to the compression of adjacent structures or intracardiac shunting caused by rupture of the SVA into the right side of the heart. Approximately $65-85 \%$ of SVAs originate from the right sinus of Valsalva, while SVAs originating from non-coronary $(10-30 \%)$ and left sinuses $(<5 \%)$ are exceedingly rare.

The most common complication is rupture into the atrium or ventricle, and, very rarely, towards the left chambers, causing left-to-right shunting or aortic valve insufficiency with congestive heart failure and the need for urgent surgical resolution. Although open-heart surgery with or without aortic valve replacement remains the treatment of choice, trans-catheter device closure of a ruptured SVA has been successfully performed. ${ }^{2}$ So far, around 136 cases of device closure of ruptured SVAs have been reported in the literature. ${ }^{3}$ For an asymptomatic unruptured SVA, there is no consensus regarding management. Most large surgical series have advocated early surgical repair even if the patient is asymptomatic, while Vural et $a l^{3}$ proposed that patients with unruptured, stable

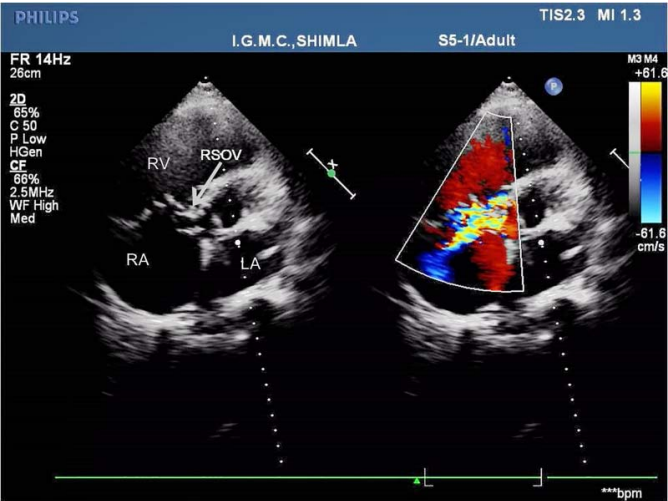

Figure 1 Transthoracic echocardiogram, parasternal short-axis view, displaying an RSOV (arrow), with colour Doppler demonstrating shunting into the right atrium (RA) near the tricuspid valve (LA, left atrium; RSOV, ruptured sinus of Valsalva; $R A$, right atrium; RV, right ventricle).

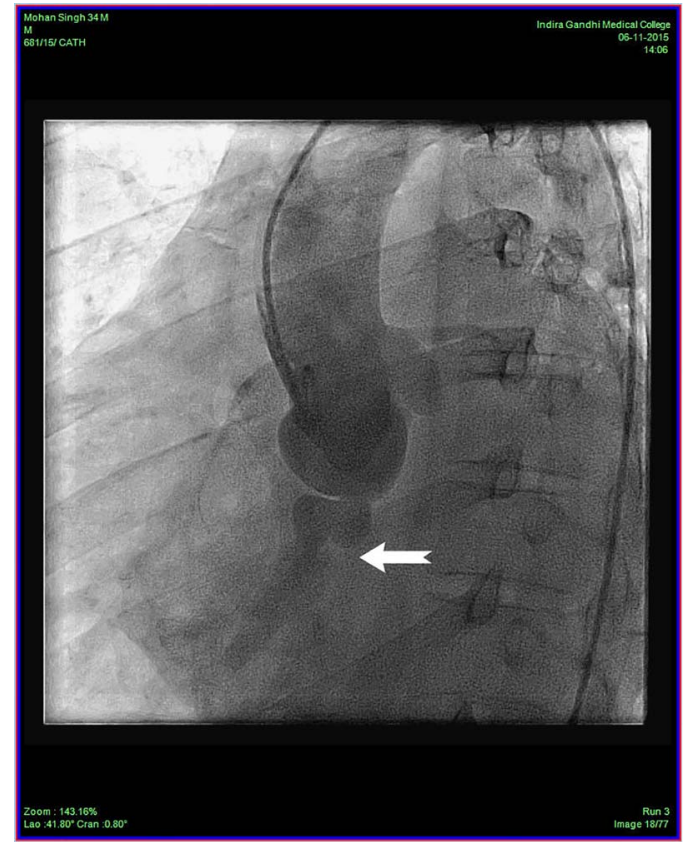

Figure 2 Aortic root angiogram showing a ruptured sinus of Valsalva aneurysm forming a windsock deformity (arrow) into the right side chambers.

aneurysms should be anticoagulated, followed at 6-month intervals, and then repaired if symptoms develop or the size of the sinus is $>50 \%$ of the average size of the other two normal Valsalva

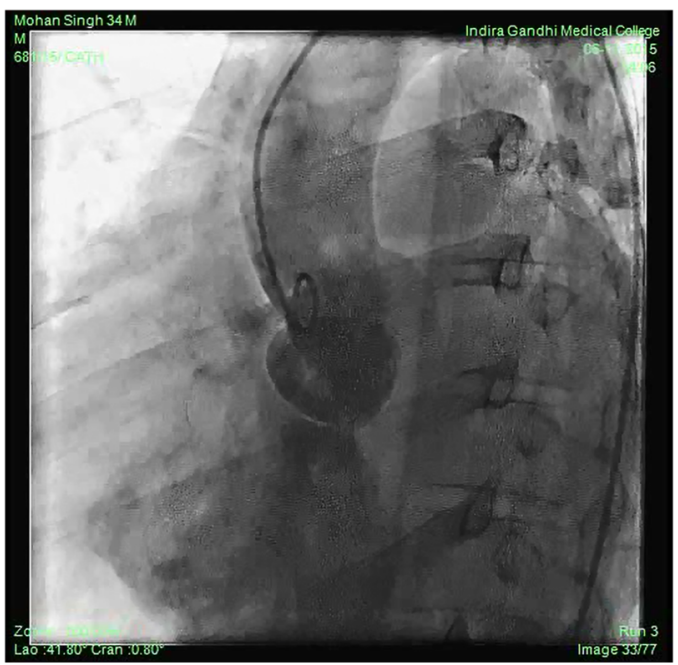

Video 1 Aortic root angiogram showing opacification of the right ventricle on aortic root injection through the ruptured sinus of Valsalva. 


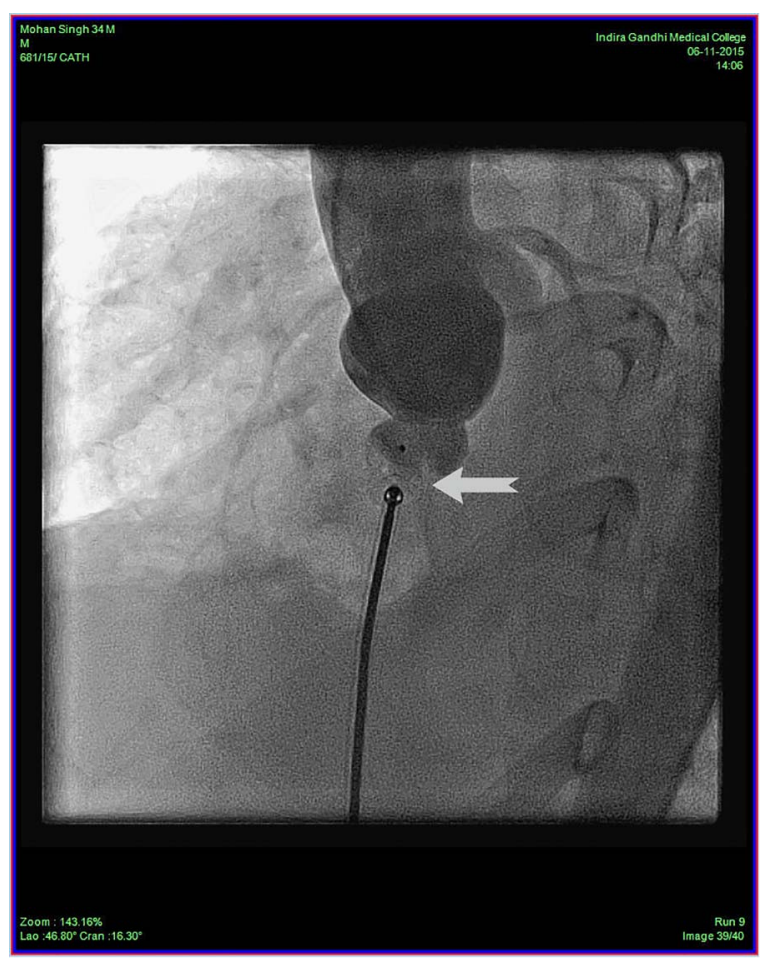

Figure 3 Aortic root angiogram showing the device (arrow) positioned across the ruptured sinus of Valsalva just before its deployment.

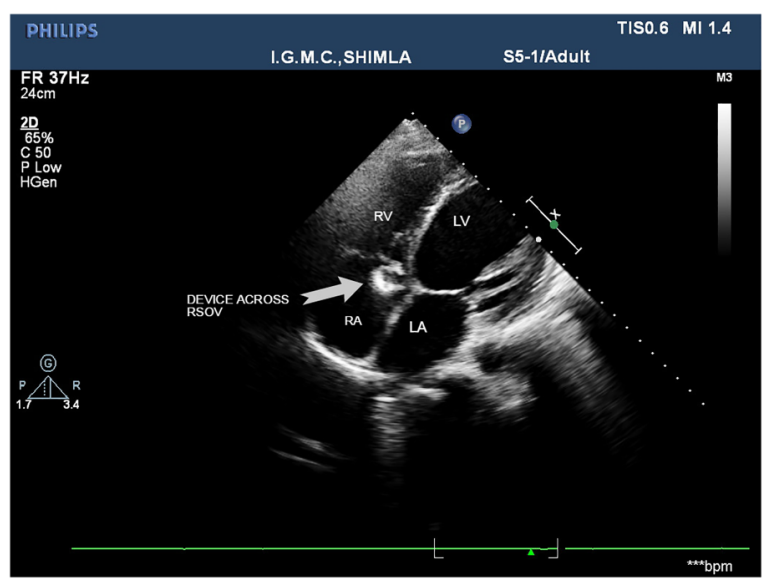

Figure 4 Transthoracic echocardiogram, apical four- chamber view, showing the device in situ (arrow) across the RSOV (LA, left atrium; LV, left ventricle; RSOV, ruptured sinus of Valsalva; RA, right atrium; RV, right ventricle).

sinuses, compresses or distorts surrounding chambers or tissues, or increases in consecutive echocardiographic examinations.

We present a case of a 34-year-old man with acute heart failure symptoms of 1 week duration. Transthoracic echocardiogram revealed a ruptured sinus of Valsalva aneurysm entering

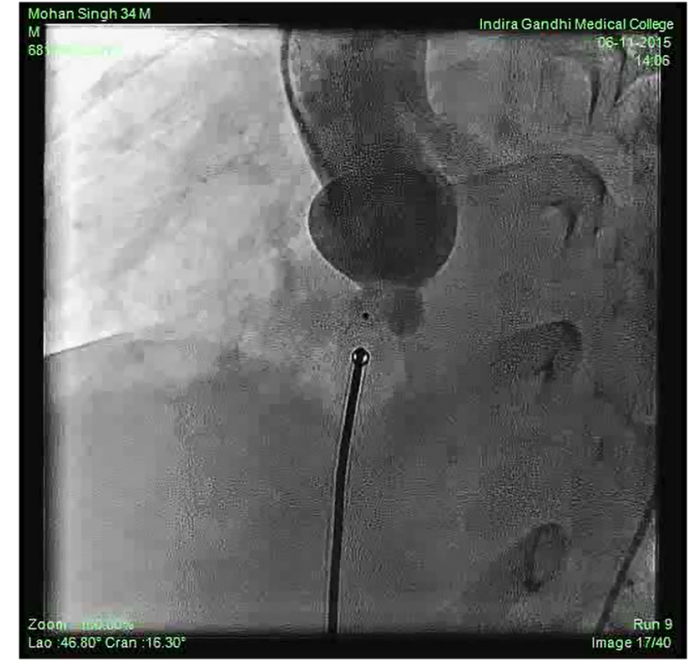

Video 2 Aortic root angiogram showing no residual shunt across the ruptured sinus of Valsalva after device deployment.

into the right ventricle (figure 1). Angiogram revealed a classical windsock deformity (figure 2 and video 1 ). Successful device closure was achieved using a 10/12 mm LIFETECH CERA PDA occlusion device. Subsequent angiogram and echocardiogram revealed no residual shunt (figures 3 and 4, and video 2). The patient was on regular follow-up for 6 months and did not have any recurrence of symptoms.

\section{Learning points}

- Ruptured sinus of Valsalva aneurysm is a rare cardiac anomaly.

- Presentation varies from asymptomatic findings to acute heart failure, which can rapidly worsen to cause death.

- Although surgery is the gold standard treatment, percutaneous transcatheter closure has now become equally efficacious with fewer complications.

\section{Competing interests None declared.}

Patient consent Obtained.

Provenance and peer review Not commissioned; externally peer reviewed.

\section{REFERENCES}

1 Prian GW, Diethrich EB. Sinus of Valsalva abnormalities. A specific differentiation between aneurysms of an aneurysms involving the sinuses of Valsalva. Vasc Surg 1973;7:155-64.

2 Zhong L, Tong SF, Zhang Q, et al. Clinical efficacy and safety of transcatheter closure of ruptured sinus of Valsalva aneurysm. Catheter Cardiovasc Interv 2014;84:1184-9.

3 Kuriakose EM, Bhatla P, McElhinney DB. Comparison of reported outcomes with percutaneous versus surgical closure of ruptured sinus of Valsalva aneurysm. Am J Cardiol 2015;115:392-8. 
Copyright 2015 BMJ Publishing Group. All rights reserved. For permission to reuse any of this content visit http://group.bmj.com/group/rights-licensing/permissions.

BMJ Case Report Fellows may re-use this article for personal use and teaching without any further permission.

Become a Fellow of BMJ Case Reports today and you can:

- Submit as many cases as you like

- Enjoy fast sympathetic peer review and rapid publication of accepted articles

- Access all the published articles

- Re-use any of the published material for personal use and teaching without further permission

For information on Institutional Fellowships contact consortiasales@bmjgroup.com

Visit casereports.bmj.com for more articles like this and to become a Fellow 